\title{
Absence of toxicity and genotoxicity in an extract of Rubus coriifolius
}

S. González-Hernández ${ }^{1}$, D. González-Ramírez ${ }^{1}$, M.I. Dávila-Rodríguez ${ }^{1}$, A. Jimenez-Arellanez ${ }^{2}$, M. Meckes-Fischer ${ }^{3}$, S. Said-Fernández ${ }^{4}$ and E.I. Cortés-Gutiérrez ${ }^{1}$

${ }^{1}$ Centro de Investigación Biomédica del Noreste, Instituto Mexicano del Seguro Social, Monterrey, NL, Mexico ${ }^{2}$ Unidad de Investigación Médica en Farmacología, UMAE Hospital de Especialidades, Centro Médico Nacional-Siglo XXI, Instituto Mexicano del Seguro Social, Mexico City, Mexico

${ }^{3}$ Centro de Diagnóstico em Metabolismo Energético y Medicina Mitocondrial, Mexico City, Mexico

${ }^{4}$ Departament of Biochemistry and Molecular Medicine, Faculty of Medicine, Autonomous University of Nuevo León, Monterrey, NL, Mexico

\section{†n memoriam}

Corresponding author: E.I. Cortés-Gutiérrez

E-mail: elvacortes@cibinmty.net

Genet. Mol. Res. 15 (4): gmr15048966

Received July 14, 2016

Accepted September 30, 2016

Published December 2, 2016

DOI http://dx.doi.org/10.4238/gmr15048966

Copyright (C) 2016 The Authors. This is an open-access article distributed under the terms of the Creative Commons Attribution ShareAlike (CC BY-SA) 4.0 License.

ABSTRACT. Rubus coriifolius Focke is a wild plant from the Rosaceae family. It grows in both Guatemala and Mexico. The polar extract of the aerial parts of this plant has antibacterial, anti-inflammatory, and anti-protozoal activities. These properties may explain the traditional use of this plant. In vivo and in vitro assays were used to assess the genotoxic and toxic effects of an ethanol extract of the aerial parts of $R$. coriifolius. Three groups of rats were orally administered the 
$R$. coriifolius extract diluted in ethanol (5\%) at doses of $1.89 \mathrm{mg} / \mathrm{kg}$ body weight (low dose), $4.72 \mathrm{mg} / \mathrm{kg}$ body weight (medium dose), and $9.44 \mathrm{mg} / \mathrm{kg}$ body weight (high dose) for 3 weeks. Genotoxic/cytotoxic effects induced by the $R$. coriifolius ethanol extract were evaluated in vivo by a micronuclei (MN) test in rat's bone marrow cells and in vitro by $\mathrm{MN}$ and sister chromatid exchange (SCE) in human lymphocyte cultures. In vivo genotoxicity analyses revealed that the average number of micronucleated polychromatic erythrocytes and the polychromatic erythrocyte/red blood cell ratio at all doses were not significantly different from those of the negative control. In vitro genotoxicity analyses showed that $\mathrm{MN}, \mathrm{SCE}$, and proliferative index frequencies in a human lymphocyte cell culture were not significantly different from those of the negative control. These results demonstrate that the ethanol extract of $R$. coriifolius aerial parts is not toxic or mutagenic (in vitro and in vivo) and does not affect cell proliferation at the concentrations analyzed.

Key words: Rubus coriifolius Focke; Rosaceae; Subacute toxicity; Micronucleus test; Genotoxic activity

\section{INTRODUCTION}

Medicinal plants are of special importance because of their role in protecting health and as preventive or supportive therapies for numerous diseases and disorders (Farnsworth et al., 1985; Farnsworth and Soejarto, 1991). Although herbal remedies are often perceived as being natural and, therefore, safe, they are not free from adverse effects; consequently, an evaluation of their safety, efficacy, and quality is necessary (Ernst, 2000; Ernst, 2006).

Rubus coriifolius Focke is a wild plant from the Rosaceae family. It grows in Guatemala and in the Mexican states of Michoacán, Veracruz, Morelos, and Chiapas. The plant is a creeper, with $10-\mathrm{m}$ long stems, thorny branches, alternate leaves, and five tiny leaves extending along the stems. Flowers are white or pink; fruits are red-black and grow in bunches. In Chiapas and other Mexican locations, people use a decoction of this plant to treat gastrointestinal disorders such as diarrhea and dysentery. In some Mexican locations, $R$. coriifolius is known as "zarzamora silvestre" (Berlin and Berlin, 1996).

The polar extract of the aerial parts of this plant has antibacterial (Meckes et al., 1995; Berlin and Berlin, 1996; Alanís et al., 2003), anti-inflammatory, and anti-protozoal activities in vivo (Meckes et al., 2004; Barbosa et al., 2006). These properties may explain the traditional use of this plant.

The micronuclei (MN) test is a widely applied assay for testing new compounds for regulatory purposes, both in vivo and in vitro (OECD, 1997; OECD, 2009). MN are masses of chromatin with the appearance of small nuclei, fragments of chromosomes, or intact whole chromosomes lagging behind at the anaphase stage of cell division. In vivo, this biomarker can be easily recognized in immature polychromatic erythrocytes because in mammals they extrude their nucleus at the terminal stage of maturation, leaving only an MN inside the cell. This results in what is called a micronucleated polychromatic erythrocyte (MN-PCE) (Schmid, 1975). The frequency of MN-PCEs reflects the level of genetic damage induced in the erythropoietic system. The value of this test in predicting carcinogenicity has been

Genetics and Molecular Research 15 (4): gmr15048966 
demonstrated (Jenssen and Ramel, 1980), and it has been proposed to be among the best short-term in vivo mutagenicity/cytotoxicity assays (Ribeiro et al., 1993). Further, the MN test in vivo has been used to determine genotoxicity of plant extracts (Raymundo et al., 2012; Traesel et al., 2015).

$\mathrm{MN}$ expression in peripheral blood lymphocytes is a well-established method to monitor chromosome damage in human populations (Thierens et al., 2000). MN results from lesions/adducts at the DNA or chromosome level or at the level of proteins that are directly or indirectly involved in chromosome segregation (e.g., tubulin). The formation of $\mathrm{MN}$ originating from chromosome fragments or chromosome-loss events requires a mitotic or meiotic division (Fenech, 1990).

The cytokinesis-block MN technique enables $\mathrm{MN}$ to be specifically scored in cells that have completed nuclear division and are, therefore, not influenced by variations in cell division kinetics. This technique has been shown to be a sensitive and reliable index of chromosome damage (Fenech et al., 1991). We used the MN assay because of its simplicity and speed, which allowed for the quick scoring of a large number of cells and resulted in an increased statistical likelihood of detecting relevant differences in chromosome damage among groups (Fenech et al., 1991).

Sister chromatid exchange (SCE) is a classic genotoxicity assay and is used to detect alterations in the biochemistry underlying cellular homologous recombination (Stults et al., 2014).

Assessing toxicity/genotoxicity of $R$. coriifolius extract is essential to determine its safety. We analyzed the effects of an ethanol extract of $R$. coriifolius on hematological, biochemical, and histopathological parameters and investigated its genotoxicity in vivo in rat bone marrow cells and in vitro in lymphocyte cultures using the MN and SCE tests. To our knowledge, this is the first report of the genotoxic effects of $R$. coriifolius collected in Mexico.

\section{MATERIAL AND METHODS}

Our study was approved by the Research and Ethics Committees of the Instituto Mexicano del Seguro Social (IMSS).

\section{Preparation of the ethanolic extract}

Aerial parts of $R$. coriifolius (leaves, stems, flowers, and seeds) were collected at Larraínzar, Chiapas, Mexico (latitude/longitude coordinates: $16.88^{\circ} \mathrm{N} / 92.71^{\circ} \mathrm{W}$ ). The plants were identified and a sample deposited at the herbarium of the IMSS, Mexico (voucher specimen No. 11874).

The vegetal material was washed with distilled water, dried, ground, and macerated in ethanol $(3 \times 12 \mathrm{~L})$ at room temperature for $72 \mathrm{~h}$. After filtration, the extract was concentrated to dryness under low pressure at $40^{\circ} \mathrm{C}$ to obtain $250 \mathrm{~g}$ of a $16 \%$ crude extract $(\mathrm{w} / \mathrm{w})$.

\section{Animals}

These studies were performed in a group of 24 male Sprague-Dawley rats aged 4 months and weighing around $450 \mathrm{~g}$. They were kept in the laboratory under standard ambient conditions $\left(25^{\circ} \pm 2^{\circ} \mathrm{C}\right.$; with a light/dark cycle of $\left.12 \mathrm{~h}\right)$. The study was carried out using these animals according to the current Official Mexican Norm for Animal Management (NOM062-ZOO-1999) (Norma Oficial Mexicana, 1999) and under the guidelines of the IMSS

Genetics and Molecular Research 15 (4): gmr15048966 
Ethical Committee. The calculated doses of the extract given to the animals were defined and extrapolated from the popular use for consumption of plant decoction of aerial parts as a water substitute (3-4 daily cups) for an adult human. Accordingly, the following doses were prepared: $1.89 \mathrm{mg} / \mathrm{kg}$ body weight (low dose, LD) (equivalent to 4 cups per day), $4.72 \mathrm{mg}$ / $\mathrm{kg}$ body weight (medium dose, MD) (equivalent to 10 cups per day), $9.44 \mathrm{mg} / \mathrm{kg}$ body weight (high dose, HD) (equivalent to 20 cups per day). The extract was diluted in $5 \%$ ethanol in water. All doses were adjusted to a total final volume of $2 \mathrm{~mL}$ for each rat.

Four groups of six animals each were randomly formed. Group 1 (control, CG) was administered $5 \%$ ethanol in water $(2 \mathrm{~mL})$ during each day of the drug administration period by means of an orogastric cannula. Groups 2, 3, and 4 (LD, MD, and HD, respectively) received the same volume of $R$. coriifolius extract diluted in 5\% ethanol in water.

The study elapsed over 3 weeks in which the rats were individually housed in conventional stainless steel cages and fed Purina Rodent Diet 5001 (LabDiet, ProLab Laboratory Animal Diet, St. Louis, MO, USA) and distilled water ad libitum. Twice a week, all rats were individually caged in metabolic cages (Nalgene ${ }^{\mathrm{TM}}$ Cat. No. 650-0100). The first week served as an adaptive period for the rats (week 1). The extract was administered from the first day of the second week until the end of the study. Animals were in a fasting state for approximately $4 \mathrm{~h}$ before receiving the extract solution.

A group of six animals treated with a unique intraperitoneal application of $20 \mathrm{mg}$ cyclophosphamide (CPA)/kg (positive control) was included in the MN test.

\section{Subjects}

Venous blood samples were obtained using heparinized sterile vacutainers (Becton Dickinson, Bradford, MA, USA) from six healthy non-smoking male volunteers who had not been exposed to chemicals, drugs, or other substances. The volunteers gave their permission to use their blood in the experiment. Two 5-mL aliquots of blood were obtained from each subject.

\section{Subacute toxicity in rats}

Body weight and water consumption were measured every week. Fecal consistency was observed daily while the extract was being administered. Any observed alterations in gait, sleep, and self-cleaning behavior during the period of drug administration were annotated. The presence or absence of possible toxic effects such as diarrhea, convulsions, etc. was carefully observed. While in the metabolic cages, urinary volume was measured every $24 \mathrm{~h}$ for each rat. Density and $\mathrm{pH}$ of these samples were semi-quantitatively measured and the possible presence of proteins, glucose, ketone bodies, leukocytes, hemoglobin, urobilinogen, bilirubin, and nitrites was also determined using Combur ${ }^{10}$ Test reactive strips (Roche Diagnostics, Indianapolis, IN, USA). The shape and consistency of rat feces were observed daily to note if any macroscopic changes had occurred such as alterations in color, presence of blood, or mucous material.

\section{Hematological, biochemical, and histopathological analyses}

At the end of the treatment period, the animals were anesthetized with diethyl ether and arterial blood was extracted from the abdominal aorta. One of two samples from each animal was anticoagulated for evaluation of hematological parameters (erythrocytes,

Genetics and Molecular Research 15 (4): gmr15048966 
total leukocytes, hemoglobin, hematocrit, differential account, and thrombocytes) using an automated hematology analyzer (CELL-DYN 1400, Abbot Diagnostics, Lake Forest, IL, USA). The other sample (without anticoagulant) was centrifuged to separate the serum for the measurement of biochemical parameters such as glucose, cholesterol, triglycerides, creatinine, blood urea nitrogen (BUN), uric acid, proteins, albumin, aspartate transaminase, and alanine transaminase in a BioSystems BTS-370 Plus autoanalyzer. Subsequently, dissection of the heart, liver, spleen, and kidneys was performed and these organs were weighed, submerged in a buffered $10 \%$ formalin solution, and processed via usual techniques for microscopic observation.

\section{MN in vivo}

The femoral bone marrow was isolated, fixed, and stained according to the Schmid criteria (Schmid, 1983). Stained slides from each group and each animal were analyzed blindly by direct observation under a light microscope at $100 \mathrm{X}$ magnification. Two procedures were carried out for each animal as follows: i) mutagenic effect: the number of MN-PCEs in 2000 cells was scored, and ii) cytotoxic effect: the number of PCEs was counted in 2000 cells and the PCE/red blood cell (RBC) ratio was estimated.

\section{Lymphocyte cultures and cell harvesting}

Heparinized peripheral blood samples obtained from six healthy, nonsmoking donors ( 3 men and 3 women, aged 18-25 years) were used in all experiments. The lymphocyte culture medium was prepared by adding $0.5 \mathrm{~mL}$ whole blood to RPMI 1640 medium (Sigma, St. Louis, MO, USA) supplemented with $20 \%$ fetal calf serum (Biochrom AG, Berlin, Germany), $100 \mathrm{IU} / \mathrm{mL}$ penicillin, $100 \mathrm{mg} / \mathrm{mL}$ streptomycin (Biological Industries, Beit-Haemek, Israel), $0.5 \mathrm{mg} / \mathrm{mL}$ L-glutamine, and $6 \mathrm{mg} / \mathrm{mL}$ phytohemagglutinin (Biochrom AG). Lymphocytes were incubated at $37^{\circ} \mathrm{C}$ for $72 \mathrm{~h}$. Dimethyl sulfoxide (DMSO, 2\%) in lymphocyte culture medium was used as a solvent control and a CPA solution $(0.5 \mu \mathrm{g} / \mathrm{mL})$ prepared in lymphocyte culture medium was used as a positive control. No substances were added to the negative control group. We studied two different doses of $R$. coriifolius extract, 3.0 and $1.5 \mathrm{mg} / \mathrm{mL}$. Because the $3.0 \mathrm{mg} / \mathrm{mL}$ dose had a strong cytotoxic effect in cell lines, we selected it as the high treatment dose for all subsequent experiments.

\section{MN in vitro}

Cytochalasin B (final concentration, $6 \mathrm{mg} / \mathrm{mL}$ ) was added at $44 \mathrm{~h}$ to block the cytokinesis process and for the MN assay; lymphocyte cultures were harvested after $72 \mathrm{~h}$. Staining of MN was performed by immersing the air-dried slides in a 5\% Giemsa solution. Two-thousand binucleated cells for each experimental point were examined according to the scoring criteria adopted by the Human MicroNucleus Project (Bonassi et al., 2001). The frequency of binucleated lymphocytes with $\mathrm{MN}$ is reported as the number of binucleated lymphocytes containing one or more MN per 1000 binucleated cells.

\section{SCE in vitro}

For SCE analyses, cultures were incubated in the dark in the presence of $10 \mathrm{mg} / \mathrm{mL}$

Genetics and Molecular Research 15 (4): gmr15048966 
5-bromodeoxyuridine (Sigma). Metaphases were obtained by adding colcemid (final concentration, $0.2 \mathrm{mg} / \mathrm{mL}$; Sigma) $2 \mathrm{~h}$ prior to harvesting. For the SCE analysis, chromosome slides were stained according to the fluorescence plus Giemsa technique (Perry and Wolff, 1974). Staining of chromosomes was performed by immersing the air-dried slides in a 5\% Giemsa solution.

The scoring criteria for SCE were based on the study of Carrano and Natarajan (1988). Well-spread, complete $(2 n=46), 50$ second-division metaphases were scored for SCE, and the frequency of SCE per cell was recorded.

The proliferation rate index (PRI) was calculated from the number of metaphases in the 200 cells analyzed per culture for each dose group and donor in the SCE assay using the following equation:

$$
\mathrm{PRI}=(\mathrm{M} 1+2 \mathrm{M} 2+3 \mathrm{M} 3) / \mathrm{N}
$$

where M1, M2, and M3 indicate the metaphases corresponding to the first, second, and third divisions, and $\mathrm{N}$ is the total number of metaphases scored (Lamberti et al., 1983). PRI was used as an indicator of adequate cell proliferation.

\section{Statistical analyses}

Statistical analyses were performed using the Statistical Package for the Social Sciences (SPSS) statistical program for Windows, version 21. Biochemical, hematological, and histopathological data are reported as means $\pm \mathrm{SD}$ for $\mathrm{N}=6$ animals per group. Oneway ANOVA and the Kruskal-Wallis test for variables without a normal distribution and nonhomogeneous variances were used to detect any differences. Significant differences among groups were detected by the Tukey and the Dunnett multiple comparison tests. The critical value for accepting a difference as significant was $\mathrm{P} \leq 0.05$.

The number of MN-PCEs and the PCE/RBC ratio in rats, as well as the number of MN/1000 binucleated cells and SCE/metaphase in leukocyte cultures treated with different extract concentrations were analyzed by one-way ANOVA with the Newman-Keuls test for multiple comparisons.

\section{RESULTS}

\section{General state of rats}

None of the rats had altered behaviors, diarrhea, mucus, or blood in feces. The rats in this study drank $33 \pm 5.5 \mathrm{~mL}$ of water daily without significant differences with respect to the $\mathrm{CG}(\mathrm{P} \leq 0.05)$.

The body weight of the animals was $471 \pm 30 \mathrm{~g}$ at the beginning of the study and $473 \pm 40 \mathrm{~g}$ upon being sacrificed ( 24 days later). We did not find any significant differences between the CG and the LD, MD, or HD groups. Similarly, we did not find any significant differences between the $\mathrm{CG}$ and $\mathrm{LD}, \mathrm{MD}$, or $\mathrm{HD}$ groups for urine volume $(11 \pm 4.4 \mathrm{~mL}$ to $18 \pm$ $7.3 \mathrm{~mL})$ and $\mathrm{pH}(6.5 \pm 0.8$ to $7.1 \pm 0.3)(\mathrm{P} \geq 0.05$, respectively, for all analyses $)$. Protein traces were detected in the urine of all groups; however, glucose levels, ketone bodies, urobilinogen, bilirubin, nitrite, and leukocytes were all normal.

Genetics and Molecular Research 15 (4): gmr15048966 


\section{Hematological and biochemical parameters}

Two significant differences were observed in the blood biometry and chemistry between the treatment groups and the CG. Specifically, thrombocyte counts were higher in the MD group (Table 1) and BUN was lower (Table 2) in the MD and HD groups than those of the $\mathrm{CG}(\mathrm{P} \leq 0.05$ for both groups).

Table 1. Hematological effect of Rubus coriifolius extract in Sprague-Dawley rats.

\begin{tabular}{|c|c|c|c|c|}
\hline \multirow[t]{2}{*}{ Parameter } & \multirow[t]{2}{*}{ Control } & \multicolumn{3}{|c|}{ Doses } \\
\hline & & Low & Medium & High \\
\hline Leucocytes $/ \mathrm{mm}^{3}$ & $8717 \pm 2183$ & $8000 \pm 2175$ & $6333 \pm 1213$ & $6133 \pm 836$ \\
\hline Neutrophils (\%) & $29 \pm 5.8$ & $23 \pm 8.2$ & $25 \pm 10$ & $34 \pm 4.6$ \\
\hline Lymphocytes (\%) & $71 \pm 5.8$ & $77 \pm 8.2$ & $76 \pm 10$ & $66 \pm 4.6$ \\
\hline Monocytes (\%) & 0 & 0 & 0 & 0 \\
\hline Eosinophils (\%) & 0 & 0 & 0 & 0 \\
\hline Basophiles (\%) & 0 & 0 & 0 & 0 \\
\hline Erythrocytes $\left(10^{6} / \mathrm{mm}^{3}\right)$ & $7.9 \pm 0.4$ & $8.3 \pm 0.6$ & $8.2 \pm 0.3$ & $7.7 \pm 0.3$ \\
\hline Hemoglobin $(\mathrm{g} / \mathrm{dL})$ & $13.7 \pm 0.9$ & $13.7 \pm 1$ & $13.9 \pm 0.6$ & $13.1 \pm 0.7$ \\
\hline Hematocrit (\%) & $40 \pm 3.7$ & $41 \pm 4.2$ & $41 \pm 4$ & $37 \pm 2.1$ \\
\hline Thrombocytes $\left(10^{3} / \mathrm{mm}^{3}\right)$ & $920 \pm 179$ & $1009 \pm 107$ & $1107 \pm 115^{1,2}$ & $878 \pm 9$ \\
\hline
\end{tabular}

Values are reported as means $\pm \mathrm{SD} .{ }^{1}$ Significantly different from control group $(\mathrm{P} \leq 0.05) .{ }^{2}$ Significantly different from high-dose group $(\mathrm{P} \leq 0.05)$.

Table 2. Effect of Rubus coriifolius extract on biochemical parameters in Sprague-Dawley rats.

\begin{tabular}{|c|c|c|c|c|}
\hline Parameter & Control & Low dose & Medium dose & High dose \\
\hline Glucose (mg/dL) & $135 \pm 30$ & $134 \pm 32$ & $153 \pm 38$ & $153 \pm 39$ \\
\hline BUN (mg/dL) & $21 \pm 0.8$ & $19 \pm 1.8$ & $18 \pm 2.1$ & $18 \pm 1.3^{*}$ \\
\hline Creatinine (mg/dL) & $0.6 \pm 0.05$ & $0.5 \pm 0.06$ & $0.6 \pm 0.1$ & $0.7 \pm 0.05$ \\
\hline Uric acid $(\mathrm{mg} / \mathrm{dL})$ & $2.5 \pm 1$ & $2.2 \pm 0.7$ & $2.3 \pm 0.8$ & $1.9 \pm 0.5$ \\
\hline Cholesterol (mg/dL) & $72 \pm 12$ & $64 \pm 11$ & $74 \pm 16$ & $73 \pm 8.5$ \\
\hline Triglycerides $(\mathrm{mg} / \mathrm{dL})$ & $123 \pm 24$ & $119 \pm 26$ & $111 \pm 23$ & $109 \pm 19$ \\
\hline Total protein $(\mathrm{g} / \mathrm{dL})$ & $6.2 \pm 0.7$ & $5.6 \pm 0.6$ & $5.5 \pm 0.8$ & $6.2 \pm 0.3$ \\
\hline Albumin (g/dL) & $2.7 \pm 0.1$ & $2.7 \pm 0.2$ & $2.7 \pm 0.2$ & $2.9 \pm 0.1$ \\
\hline Globulin (g/dL) & $3.5 \pm 0.7$ & $2.9 \pm 0.4$ & $2.9 \pm 0.5$ & $3.3 \pm 0.3$ \\
\hline Ratio A/G & $0.8 \pm 0.1$ & $1 \pm 0.1$ & $0.9 \pm 0.1$ & $0.9 \pm 0.1$ \\
\hline$\overline{\mathrm{AST}}(\mathrm{U} / \mathrm{L})$ & $175 \pm 15$ & $162 \pm 31$ & $160 \pm 49$ & $167 \pm 18$ \\
\hline$\overline{\mathrm{ALT}}(\mathrm{U} / \mathrm{L})$ & $101 \pm 20$ & $99 \pm 13$ & $92 \pm 27$ & $110 \pm 20$ \\
\hline Lactic dehydrogenase (U/L) & $2165 \pm 741$ & $2685 \pm 1415$ & $2468 \pm 1412$ & $3134 \pm 1293$ \\
\hline
\end{tabular}

Values are reported as mean $\pm \mathrm{SD}$. *Significantly different from control group $(\mathrm{P} \leq 0.05)$. ALT $=$ alanine transaminase; $\mathrm{AST}=$ aspartate transaminase; $\mathrm{A} / \mathrm{G}=$ albumin/globulin ratio; $\mathrm{BUN}=$ blood urea nitrogen.

\section{Histopathological analyses}

Spleen weight was significantly lower in the MD group than that of the CG group (P $\leq 0.05$ ) (Table 3). In addition, all animals that were treated with a high dose of extract showed slight spleen congestion. One control rat had a Wilms' tumor in one of its kidneys.

\section{MN and cytotoxic effect in vivo}

Table 4 shows the MN test results obtained in male Sprague-Dawley rats treated with $R$. coriifolius extract, including the number of MN-PCEs for each animal and means for 
untreated controls and treated animals. There were no significant differences in the number of MN-PCEs observed among groups receiving the three high doses of plant extract $(\mathrm{P} \geq 0.05)$.

Table 3. Weight ( $\mathrm{g}$ ) of the different organs taken for the histopathological assessment of the study groups.

\begin{tabular}{l|c|c|c|c}
\hline \multirow{2}{*}{ Organs } & \multicolumn{4}{|c}{ Study groups } \\
\cline { 2 - 5 } & Control & Low dose & Medium dose & High dose \\
\hline Liver & $15.3 \pm 0.9$ & $14.2 \pm 0.3$ & $14.2 \pm 0.1$ & $14.5 \pm 1$ \\
\hline Spleen & $1.01 \pm 0.04$ & $0.98 \pm 0.07$ & $0.84 \pm 0.02^{1,2}$ & $0.99 \pm 0.06$ \\
\hline Kidney & $1.37 \pm 0.19$ & $1.32 \pm 0.2$ & $1.23 \pm 0.03$ & $1.33 \pm 0.1$ \\
\hline Heart & $1.61 \pm 0.17$ & $1.41 \pm 0.04$ & $1.46 \pm 0.07$ & $1.62 \pm 0.1$ \\
\hline
\end{tabular}

Values are reported as means \pm standard deviation. ${ }^{1}$ Significantly different from control group $(\mathrm{P} \leq 0.05)$. ${ }^{2}$ Significantly different from high-dose group $(\mathrm{P} \leq 0.05)$.

Table 4. Micronuclei in bone marrow cells from rats that were treated with different concentrations of Rubus coriifolius extract.

\begin{tabular}{l|c|c|c|c|c}
\hline Group & $\mathrm{N}$ & PCE $($ mean \pm SD) & NCE (mean \pm SD) & MN-PCE (mean \pm SD) & PCE/Er $(\mathrm{mean} \pm$ SD) \\
\hline Negative control & 6 & $882.7 \pm 375.45$ & $1117.3 \pm 248.37$ & $4.3 \pm 2.14^{\mathrm{a}}$ & $0.44 \pm 0.06^{\mathrm{a}}$ \\
\hline LD & 6 & $815.5 \pm 481.87$ & $1184.5 \pm 327.36$ & $6.3 \pm 1.37^{\mathrm{a}}$ & $0.41 \pm 0.04^{\mathrm{a}}$ \\
\hline MD & 6 & $715.3 \pm 289.18$ & $1284.7 \pm 452.86$ & $7.2 \pm 3.12^{\mathrm{a}}$ & $0.36 \pm 0.05^{\mathrm{a}}$ \\
\hline HD & 6 & $695.2 \pm 385.71$ & $1304.8 \pm 278.36$ & $7.6 \pm 4.57^{\mathrm{a}}$ & $0.35 \pm 0.07^{\mathrm{a}}$ \\
\hline Positive control (CPA) & 6 & $236.1 \pm 169.52$ & $1763.9 \pm 628.48$ & $24.0 \pm 8.35$ & $0.12 \pm 0.08$ \\
\hline
\end{tabular}

$\mathrm{PCE}=$ polychromatic erythrocytes; $\mathrm{NCE}=$ normocromatic erythrocytes; $\mathrm{Er}=$ total erythrocytes (2000/individual); $\mathrm{CPa}=$ cyclophosphamide. ${ }^{a}$ Different from positive control $(\mathrm{P}<0.05)$.

The distribution of the PCE/RBC ratio in the bone marrow of rats treated with three different doses of $R$. coriifolius extract is shown in Table 4. There were no significant differences in MN-PCEs and PCE/RBC between all doses tested and the negative control. As expected, the animals that were treated with CPA alone had a higher frequency of MN-PCEs and a lower PCE/RBC ratio in bone marrow cells than the $R$. coriifolius extract-treated groups and the negative control $(\mathrm{P} \leq 0.001)$.

\section{Genotoxicity in vitro}

The distribution of MNs, SCEs, and PRI in leukocyte cultures after treatment with DMSO (solvent control), two different doses of $R$. coriifolius extract ( 3.0 and $1.5 \mathrm{mg} / \mathrm{mL}$ ), and CPA (positive control) is shown in Table 5. MN per 1000 binucleated cells, SCE per metaphase, and PRI from the two doses tested were not significantly different from those of the negative control; however, SCE per metaphase and PRI were significantly different from those of the positive control (Table 5).

Table 5. Results of micronuclei, sister chromatid exchange, and proliferative index assays in cultured human lymphocytes treated with Rubus coriifolius extract.

\begin{tabular}{l|c|c|c|c}
\hline Treatment & $\mathrm{N}$ & MN/1000 (mean \pm SD) & SCE/Metaphase $($ mean \pm SD) & PRI (mean \pm SD) \\
\hline Negative control & 6 & $1.00 \pm 0.68$ & $7.71 \pm 1.35^{\mathrm{a}}$ & $2.22 \pm 0.17^{\mathrm{a}}$ \\
\hline $3.0 \mathrm{mg}$ extract $/ \mathrm{mL}$ & 6 & $1.30 \pm 0.83$ & $7.32 \pm 0.82^{\mathrm{a}}$ & $2.00 \pm 0.06^{\mathrm{a}}$ \\
\hline $1.5 \mathrm{mg}$ extract $/ \mathrm{mL}$ & 6 & $1.10 \pm 1.24$ & $6.77 \pm 2.11^{\mathrm{a}}$ & $2.28 \pm 0.14^{\mathrm{a}}$ \\
\hline Positive control & 6 & $9.66 \pm 2.14$ & $13.00 \pm 0.76$ & $1.75 \pm 0.23$ \\
\hline
\end{tabular}

$\mathrm{MN}=$ micronuclei; $\mathrm{PRI}=$ proliferative index. ${ }^{\text {aDifferent }}$ from the positive control, $\mathrm{P}<0.05$.

Genetics and Molecular Research 15 (4): gmr15048966 


\section{DISCUSSION}

Extracts from plant species have provided an alternative and additional source of novel natural therapeutic compounds and have attracted considerable attention in the biomedical field. Toxic and mutagenic/cytotoxic potential of medicinal plants such as $R$. coriifolius are the most important nonclinical safety studies for the approval and marketing of these products.

Mexican health laws demand preclinical toxicological studies of any product of natural origin intended to be used for human consumption (Ley General de Salud, 2014).

\section{Subacute toxicity in rats}

R. coriifolius extract was orally administered each day for a period of 2 weeks and did not cause observable changes in behavior, feeding habits, water consumption, voided urinary volume, body weight, etc., at the doses tested. In both the extract treated and control groups we found trace amounts of protein present in the urine. We believe that this observation is a normal occurrence for this particular animal breed. The number of thrombocytes was higher in the MD group than that of the other treatment groups - an effect that was not dose-dependent (Table 1); data from the individual animals show that a single animal raised the overall mean for the whole group, suggesting this result may be attributable to an outlier. A significant difference in BUN levels was found in the HD group (Table 2). In addition, BUN levels were significantly lower in the HD group than those of the CG group were. These differences may be explained by a failure in the production of this metabolite because of damage to the organs responsible for producing blood urea; however, this explanation is not likely based on other results showing a lack of toxicity.

No histopathological findings were noted that could be attributed to administration of the $R$. coriifolius extract. The Wilms' tumor detected in the CG group was an unexpected result that is not associated with exposure to $R$. coriifolius extract.

In 2000, the World Health Organization (WHO, 2000) made some adaptations to the research protocols used for evaluating the efficacy and safety of herbal medical products. These changes constitute the current normalized nonclinical toxicology studies that are accepted for the evaluation of this type of medication.

Currently, databases from botanical collections and surveys have generated information on medicinal native plants used by the Mayas from Altos de Chiapas, according to their use, handling, preparation, and administration, thus contributing to a global effort in the search of new drugs (De la Cruz-Jiménez et al., 2014).

It is possible to observe the excretion of abnormal metabolites and the alteration of biological indicators in confined laboratory animals (Gonzalez-Ramirez et al., 2006). After sacrifice, it is also possible to observe changes in the usual level of serum markers, which is indicative of possible damage to the central nervous system and hepatic (e.g., transaminases), renal (creatinine and urea), and digestive (volume, content, and consistency of feces) systems, etc. (González-Ramírez et al., 1985).

Pharmacological and phytochemical studies performed at the IMSS have shown that the shoots and leaves of $R$. coriifolius are useful for compounding agents having antibacterial, antiprotozoal, and antisecretory properties, as well as for inhibiting intestinal transit. Seven active principles have been isolated from $R$. coriifolius, including (-)-epicatechin, $(+)$-catechin, hyperin, nigaichigoside $\mathrm{F} 1, \beta$-sitosterol 3-O- $\beta \mathrm{D}$-glucopyranoside, gallic acid, and ellagic acid

Genetics and Molecular Research 15 (4): gmr15048966 
(Alanís et al., 2003). All of these compounds have antiprotozoal activity against Entamoeba histolytica and Giardia lambia (Calzada et al., 1998); (-)-epicatechin is the main component responsible for the antiprotozoal properties, with activity comparable to that of emetine, but less than that of metronidazole (Barbosa et al., 2007).

Genetic toxicology tests are designed to detect compounds that induce genetic damage directly or indirectly. DNA damage can result in gene mutations, loss of heterozygosity, and chromosome aberrations. These events may play an important role in many malignancies and may induce inheritable effects that lead to birth defects. Thus, identifying genotoxic effects of any agent is important for the risk/benefit assessment of its use in humans.

As no documented results are available about the potential genetic toxicity of $R$. coriifolius, we initiated these studies to address this question.

\section{Genotoxicity (in vivo and in vitro)}

In this study, combinations of in vivo and in vitro assays were applied to investigate the possible genotoxicity of an extract of $R$. coriifolius aerial parts.

The incidence of MN in polychromatic erythrocytes and the ratio of polychromatic erythrocytes to normochromatic erythrocytes analyzed in the bone marrow cells of rats treated with an extract of $R$. coriifolius were not significantly different from those detected in the negative control group $(\mathrm{P}>0.05)$. These results are indicative of the absence of a mutagenic effect and lack of cytotoxicity of the different treatments under these conditions, respectively.

A mutagenic effect was not detected in vitro by the MN and SCE assays in leukocytes from peripheral blood. The PRI analysis demonstrated adequate cell proliferation.

Studies addressing the genotoxic or mutagenic potential of plants from the Rubus genus are very scarce in the literature. The mutagenic potential of a Rubus idaeus acetone extract was investigated in vitro using the Ames test. The results obtained did not show any mutagenic effects or cytotoxicity against Caco-2 cells (Kreander et al., 2006). Tolentino et al. (2015) demonstrated the absence of genotoxic and mutagenic effects in a Rubus niveus extract $(500,1000$, and $2000 \mathrm{mg} / \mathrm{kg}$ ) using a comet assay. The results described above are in agreement with the results obtained in our study in which the absence of genotoxic, mutagenic, and cytotoxic effects for $R$. coriifolius were also verified. However, Alves et al. (2014) reported an increase in the frequency of MN after treatment with Rubus imperialis extracts $(250$ and $500 \mathrm{mg} / \mathrm{kg})$.

\section{CONCLUSIONS}

In the present study, we evaluated for the first time the toxic/genotoxic potential of an $R$. coriifolius extract. The results indicate that the pure extract does not induce a significant increase in the mean number of cells with DNA strand breaks or MN after subchronic treatments. Further studies are needed to evaluate the safety of higher doses or chronic consumption of this extract.

\section{Conflicts of interest}

The authors declare no conflict of interest.

Genetics and Molecular Research 15 (4): gmr15048966 


\section{ACKNOWLEDGMENTS}

The authors thank Dr. Xavier Lozoya Legorreta for his support and confidence, which were essential for this study, and Abigail Aguilar, M.Sc., who identified, collected, classified, and registered the vegetal material used in this study. Collaborative work was performed under the auspices of the Iberoamerican Program for Science and Technology (CYTED), Project X.11: PIBATUB. Research supported by FOFOI/IMSS, through the grant \#IMSS-2002/216.

\section{REFERENCES}

Alanís AD, Calzada F, Cedillo-Rivera R and Meckes M (2003). Antiprotozoal activity of the constituents of Rubus coriifolius. Phytother. Res. 17: 681-682. http://dx.doi.org/10.1002/ptr.1150

Alves AB, dos Santos RS, Calil SdeS, Niero R, et al. (2014). Genotoxic assessment of Rubus imperialis (Rosaceae) extract in vivo and its potential chemoprevention against cyclophosphamide-induced DNA damage. J. Ethnopharmacol. 153: 694-700.http://dx.doi.org/10.1016/j.jep.2014.03.033

Barbosa E, Calzada F and Campos R (2006). Antigiardial activity of methanolic extracts from Helianthemum glomeratum Lag. and Rubus coriifolius Focke in suckling mice CD-1. J. Ethnopharmacol. 108: 395-397. http://dx.doi. org/10.1016/j.jep.2006.05.026

Barbosa E, Calzada F and Campos R (2007). In vivo antigiardial activity of three flavonoids isolated of some medicinal plants used in Mexican traditional medicine for the treatment of diarrhea. J. Ethnopharmacol. 109: 552-554.http:// dx.doi.org/10.1016/j.jep.2006.09.009

Berlin B and Berlin E (1996). Medical ethnobiology of the highland of Chiapas, Mexico. The gastrointestinal diseases. Princeton University Press, New Jersey.

Bonassi S, Fenech M, Lando C, Lin YP, et al. (2001). HUman MicroNucleus project: international database comparison for results with the cytokinesis-block micronucleus assay in human lymphocytes: I. Effect of laboratory protocol, scoring criteria, and host factors on the frequency of micronuclei. Environ. Mol. Mutagen. 37: 31-45. http://dx.doi. org/10.1002/1098-2280(2001)37:1<31::AID-EM1004>3.0.CO;2-P

Calzada F, Alanis AD, Meckes M, Tapia-Contreras A, et al. (1998). In vitro susceptibility of Entamoeba histolytica and Giardia lamblia to some medicinal plants used by the people of southern Mexico. Phytother. Res. 12: 70-72. http:// dx.doi.org/10.1002/(SICI)1099-1573(19980201)12:1<70::AID-PTR189>3.0.CO;2-V

Carrano AV and Natarajan AT (1988). International Commission for Protection Against Environmental Mutagens and Carcinogens. ICPEMC publication no. 14. Considerations for population monitoring using cytogenetic techniques. Mutat. Res. 204: 379-406. http://dx.doi.org/10.1016/0165-1218(88)90036-5

De la Cruz-Jiménez L, Guzmán-Lucio M and Viveros-Valdez E (2014). Traditional medicinal plants used for the treatment of gastrointestinal diseases in Chiapas, México. World Appl. Sci. J. 31: 508-515.

Ernst E (2000). Prevalence of use of complementary/alternative medicine: a systematic review. Bull. World Health Organ. 78: 252-257.

Ernst E (2006). Herbal remedies for anxiety - a systematic review of controlled clinical trials. Phytomedicine 13: 205-208. http://dx.doi.org/10.1016/j.phymed.2004.11.006

Farnsworth NR and Soejarto DD (1991). Global importance of medicinal plants. In: The conservation of medicinal plants (Akerele O, Heywood V and Synge H, eds.). Cambridge University Press, Cambridge, 25-52.

Farnsworth NR, Akerele O, Bingel AS, Soejarto DD, et al. (1985). Medicinal plants in therapy. Bull. World Health Organ. 63: 965-981.

Fenech M (1990). The cytokinesis-block micronucleus assay in nucleated cells. Prog. Clin. Biol. Res. 340B: 195-206.

Fenech MF, Dunaiski V, Osborne Y and Morley AA (1991). The cytokinesis-block micronucleus assay as a biological dosimeter in spleen and peripheral blood lymphocytes of the mouse following acute whole-body irradiation. Mutat. Res. 263: 119-126. http://dx.doi.org/10.1016/0165-7992(91)90069-G

Gonzalez-Ramirez D, Gonzalez-Hernandez S and Lopez-Franco JJ (2006). Toxicidad subaguda y crónica de extractos de naturales o sintéticos. In: Manual de técnicas de bioevaluación de nuevos agentes anti-tuberculosis. Programa Iberoamericano de Ciencia y Tecnología para el Desarrollo. (Said S, Del Olmo E, Leal C, San Feliciano A eds). CYTED España.

González Ramírez D, Hernández RM, Bolado C and García Delgado J (1985). Estudio de la posible actividad anticonvulsiva de la raíz de Ipomoea stans. Salud Publica Mex. 27: 485-491.

Genetics and Molecular Research 15 (4): gmr15048966 
Jenssen D and Ramel C (1980). The micronucleus test as part of a short-term mutagenicity test program for the prediction of carcinogenicity evaluated by 143 agents tested. Mutat. Res. 75: 191-202. http://dx.doi.org/10.1016/0165$1110(80) 90014-7$

Kreander K, Galkin A, Vuorela S, Tammela P, et al. (2006). In-vitro mutagenic potential and effect on permeability of coadministered drugs across Caco-2 cell monolayers of Rubus idaeus and its fortified fractions. J. Pharm. Pharmacol. 58: 1545-1552. http://dx.doi.org/10.1211/jpp.58.11.0016

Lamberti L, Bigatti Ponzetto P and Ardito G (1983). Cell kinetics and sister-chromatid-exchange frequency in human lymphocytes. Mutat. Res. 120: 193-199. http://dx.doi.org/10.1016/0165-7992(83)90163-X

Ley General de Salud (2014). Título quinto. Investigación para la Salud. Capítulo único. (Última reforma publicada DOF 15-01-2014).

Meckes M, Villareal ML, Tortoriello J, Berlin B, et al. (1995). A microbiological evaluation of medicinal plants used by the Maya people of Southern Mexico. Phytother. Res. 9: 244-250. http://dx.doi.org/10.1002/ptr.2650090403

Meckes M, David-Rivera AD, Nava-Aguilar V and Jimenez A (2004). Activity of some Mexican medicinal plant extracts on carrageenan-induced rat paw edema. Phytomedicine 11: 446-451. http://dx.doi.org/10.1016/j.phymed.2003.06.002

Norma Oficial Mexicana (1999). Especificaciones técnicas para la producción, cuidado y uso de los animales de laboratorio (NOM-062-ZOO-1999). Available at [http://www.fmvz.unam.mx/fmvz/principal/archivos/062ZOO.PDF]

OECD (1997). OECD guideline for the testing of chemicals, No. 474: mammalian erythrocyte micronucleus test. Organization for Economic Cooperation and Development: Paris, France.

OECD (2009). OECD guideline for the testing of chemicals, No. 487: In vitro mammalian cell micronucleus test (MNvit). Organization for Economic Cooperation and Development: Paris, France. http://ntp.niehs.nih.gov/iccvam/suppdocs/ feddocs/oecd/oecd-tg489-2014.pdf

Perry P and Wolff S (1974). New Giemsa method for the differential staining of sister chromatids. Nature 251: 156-158. http://dx.doi.org/10.1038/251156a0

Raymundo TM, Favilla M, Niero R, Andrade SF, et al. (2012). Genotoxicity of the medicinal plant Maytenus robusta in mammalian cells in vivo. Genet. Mol. Res. 11: 2847-2854.http://dx.doi.org/10.4238/2012.August.24.9

Ribeiro LG, Takahashi CS, Erdtman B, Oliveira SV, et al. (1993). Inter-laboratory calibration program for the mouse micronuclei test. Rev. Bras. Genet. 16: 631-638.

Schmid W (1975). The micronucleus test. Mutat. Res. 31: 9-15.http://dx.doi.org/10.1016/0165-1161(75)90058-8

Schmid W (1983). The micronucleus test for cytogenetic analyses. In: Chemical mutagens, principles and methods for their detection (Hollaender A ed.), Plenum, New York. 31-53.

Stults DM, Killen MW and Pierce AJ (2014). The sister chromatid exchange (SCE) assay. Methods Mol. Biol. 1105: 439455.http://dx.doi.org/10.1007/978-1-62703-739-6 32

Thierens H, Vral A, Morthier R, Aousalah B, et al. (2000). Cytogenetic monitoring of hospital workers occupationally exposed to ionizing radiation using the micronucleus centromere assay. Mutagenesis 15: 245-249. http://dx.doi. org/10.1093/mutage/15.3.245

Tolentino F, Araújo PA, Marques EdeS, Petreanu M, et al. (2015). In vivo evaluation of the genetic toxicity of Rubus niveus Thunb. (Rosaceae) extract and initial screening of its potential chemoprevention against doxorubicin-induced DNA damage. J. Ethnopharmacol. 164: 89-95. http://dx.doi.org/10.1016/j.jep.2015.02.013

Traesel GK, Castro LH, Silva PV, Muzzi RM, et al. (2015). Assessment of the cytotoxic, genotoxic, and mutagenic potential of Acrocomia aculeata in rats. Genet. Mol. Res. 14: 585-596. http://dx.doi.org/10.4238/2015.January.26.13

WHO (2000). Pautas generales para las metodologías de investigación y evaluación de la medicina tradicional. WHO (WHO/EDM/TRM/2000.1), Ginebra.

Genetics and Molecular Research 15 (4): gmr15048966 